\title{
Continental subduction channel processes: Plate interface interaction during continental collision
}

\author{
ZHENG YongFei ${ }^{*}$, ZHAO ZiFu \& CHEN YiXiang \\ CAS Key Laboratory of Crust-Mantle Materials and Environments, School of Earth and Space Sciences, \\ University of Science and Technology of China, Hefei 230026, China
}

Received July 18, 2013; accepted July 22, 2013; published online August 26, 2013

\begin{abstract}
The study of subduction-zone processes is a key to development of the plate tectonic theory. Plate interface interaction is a basic mechanism for the mass and energy exchange between Earth's surface and interior. By developing the subduction channel model into continental collision orogens, insights are provided into tectonic processes during continental subduction and its products. The continental crust, composed of felsic to mafic rocks, is detached at different depths from subducting continental lithosphere and then migrates into continental subduction channel. Part of the subcontinental lithospheric mantle wedge, composed of peridotite, is offscrapped from its bottom. The crustal and mantle fragments of different sizes are transported downwards and upwards inside subduction channels by the corner flow, resulting in varying extents of metamorphism, with heterogeneous deformation and local anatexis. All these metamorphic rocks can be viewed as tectonic melanges due to mechanical mixing of crust- and mantle-derived rocks in the subduction channels, resulting in different types of metamorphic rocks now exposed in the same orogens. The crust-mantle interaction in the continental subduction channel is realized by reaction of the overlying ancient subcontinental lithospheric mantle wedge peridotite with aqueous fluid and hydrous melt derived from partial melting of subducted continental basement granite and cover sediment. The nature of premetamorphic protoliths dictates the type of collisional orogens, the size of ultrahigh-pressure metamorphic terranes and the duration of ultrahigh-pressure metamorphism.
\end{abstract}

continental collision, subduction channel, ultrahigh-pressure metamorphism, differential exhumation, tectonic melange

Citation: Zheng Y F, Zhao Z F, Chen Y X. Continental subduction channel processes: Plate interface interaction during continental collision. Chin Sci Bull, 2013, 58: 4371-4377, doi: 10.1007/s11434-013-6066-x

In continental collision orogens, exposed ultrahigh-pressure (UHP) metamorphic terranes contain the lithotectonic records of Alpine-type subduction [1]. These records highlight metamorphic P-T conditions and mass transfers, indicating subduction of continental crustal rocks to mantle depths of over $100 \mathrm{~km}$. The UHP terranes are characterized by minor occurrences of mafic eclogites and ultramafic peridotites that are hosted by felsic gneisses. Such UHP eclogite-facies parageneses are absent in Pacific-type subduction zones [2]. These UHP rocks are of crustal and mantle protoliths and now occur together with their lower pressure counterparts in continental collision orogens [3]. It is intriguing how the continental crust is subducted to mantle depths for UHP metamorphism, how UHP slices are exhumed from mantle

*Corresponding author (email: yfzheng@ustc.edu.cn) depths to crustal levels, and how metamorphic rocks of different P-T conditions occur together in the same orogens.

The property of plate interface in subduction zones is a key to physical and chemical interactions at interplate boundaries. Physical and chemical transfers at convergent plate margins can occur on various spatial and temporal scales, which is fundamental to subduction-zone processes. Like the plate tectonic theory, the concept of subduction channel was originally developed from the tectonics of oceanic subduction zone [4-6]. It was primarily focused on the plate interface interaction in oceanic subduction zones, and now it has being extended to continental subduction zone [7]. Although this concept has been used in studying the occurrence of metamorphic rocks in oceanic subduction zones [8-10], it is just at the beginning of its application to continental collision orogens. Despite the difference in the tectonic mechanism for 
subduction and exhumation of continental curst, it is certain that crustal and mantle materials at the place interface are variably detached into subduction channel during the processes of subduction and exhumation. Although the UHP terranes of continental subduction zone exhibit different areas of exposure, different rates of exhumation and different extents of anatexis, their formation and evolution can be well explained by tectonic processes in continental subduction channel. The aim of this study is to highlight these processes in continental subduction channel that serve as the mechanism responsible for mixing and transport of crust- and mantle-derived materials during continental collision.

\section{Subduction channel processes}

On the basis of tectonic processes in subduction zones, the subduction channel is assumed as variable sizes of free space and therein material between the upper and lower plates during slab subduction into the mantle. Thus, the oceanic subduction channel denotes the free space between the underlying subduction slab and the overlying mantle wedge, in which supracrustal materials of subducting lithosphere are detached into oceanic subduction channel by tectonic offscrapping along channel walls with varying extents of deformation and metamorphism. This concept is extended to continental subduction zones [7], in which not only variable sizes of crustal fragment are detached from subducted continental lithosphere but also variable sizes of mantle fragments are offscrapped from the bottom of mantle wedge (Figure 1). These detached materials experience variable extents of metamorphism with heterogeneous deformation and local anatexis, forming a variety of tectonic melanges in continental subduction channel. The mantle wedge overlying the continental subduction channel is cooler than that overlying the oceanic subduction channel, leading to significantly lower geotherms in the continental subduction channel than those in the oceanic subduction channel. This is also the reason why the UHP metamorphic rocks of continental subduction zone are able to be preserved without complete melting following their formation at mantle depths.

Because of the difference in topography on the plate surface, the subduction channel exhibits variable sizes. But it is very narrow on the plate scale. Oceanic subduction channel is usually of small size, varying from $<1 \mathrm{~km}$ to $>10 \mathrm{~km}$. In contrast, continental subduction channel is usually of large size, varying from $>5 \mathrm{~km}$ to $>30 \mathrm{~km}$. With the progressive convergence between two plates, material inside the subduction channel forms ductile shear zone to exhibit a dynamic structure of the jelly sandwich. The crust- and mantle-derived fragments are transported either downwards or upwards during subduction, depending on the direction of corner flow inside the subduction channel. While some fragments may be transported downwards for further burial, the other fragments may be transported upwards for exhumation.

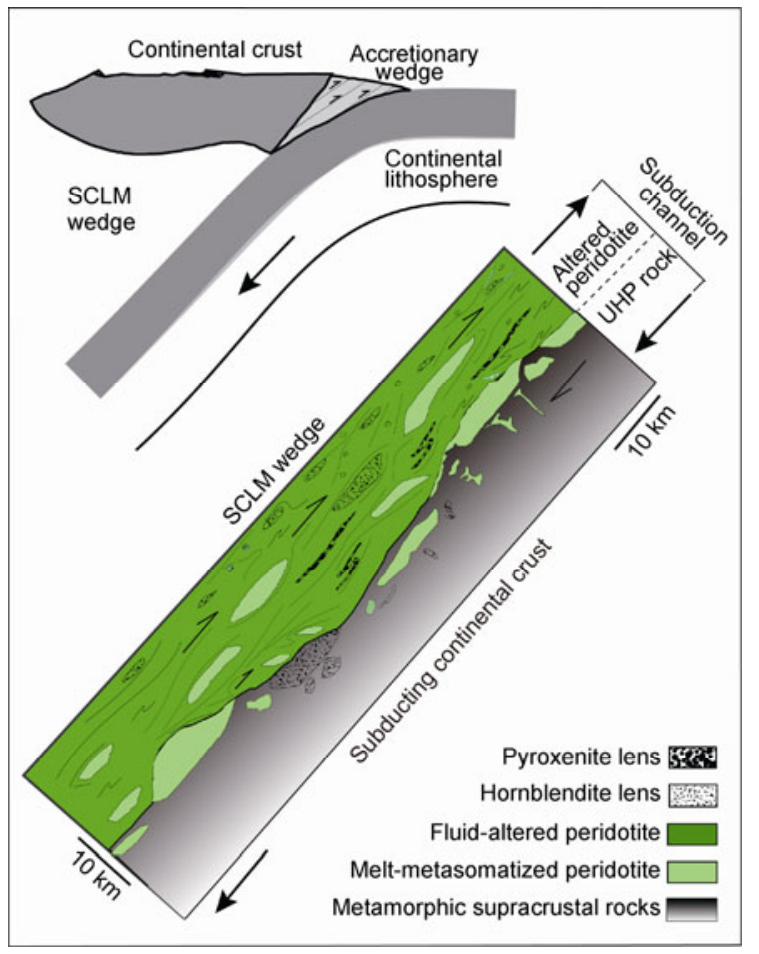

Figure 1 Schematic diagram of crust-mantle interaction in continental subduction channel (revised after Zheng [7]). The continental crust (crystalline basement and sedimentary cover), variably concentrated with water and other incompatible elements, is subducted to mantle depths, contributing major and trace elements to the subcontinental lithospheric mantle (SCLM) wedge for crustal metasomatism.

It is common in the subduction channel that the upper lowT/HP layer becomes exhumed when the lower high-T/UHP layer is still subducting. Some fragments may be rotated inside the subduction channel, resulting in different $P-T-t$ paths for different positions of a given UHP slice. These differential processes of subduction and exhumation are recorded by HP and UHP metamorphic rocks in the same collision orogens. Some UHP metamorphosed fragments may be stored in the lower crustal level for long periods, leading to significant retrogression and even thermodynamic reequilibration in the late stage of continental collision.

The tectonic behavior of subducted materials commonly exhibits a wide variation at convergent continental margins. In the Dabie-Sulu orogenic belt, for example, low to negative $\delta^{18} \mathrm{O}$ rocks of supracrustal origin were subducted to mantle depths [11], whereas a deformed accretionary wedge was accumulated at the continental margins without subduction to mantle depths [12]. These differences can be explained by three levels of crustal detachment at different depths during continental subduction: (1) the shallow detachment between sedimentary cover and crystalline basement, (2) the intermediate detachment between the upper crust and the lower crust, and (3) the deep detachment between the continental crust and the subcontinental lithospheric mantle (SCLM). The continental crust is detached at different depths, yielding different sizes of fragments and 
slices in the subduction channel. Some detached slices may be rotated inside the subduction channel. This explains the observation of Rubatto et al. [13] at Sesian in the Italian Western Alps where two stages of eclogite-facies metamorphism occurs in a single unit.

Because continental subduction channel has significantly lower temperatures than oceanic subduction channel, UHP metamorphism at mantle depths exhibit significantly lower temperatures in the continental subduction channel than those at the bottom of subarc mantle overlying the oceanic subduction channel. As a consequence, dehydration of deeply subducting crustal rocks at subarc mantle depths is much less significant in the continental subduction channel than in the oceanic subduction channel. This explains why no synsubduction arc magmatism occurs above the overridding continental lithosphere. Nevertheless, the SCLM wedge peridotite would undergo alteration and metasomatism, respectively, by aqueous fluid and hydrous melt derived from subducting continental crust and its derived fragments [7]. On the other hand, dehydration of UHP metamorphic rocks is significant during their exhumation from mantle depths toward the crust [14]. This type of retrograde fluid action is particularly profound in the lower crustal level, leading to amphibolite-facies retrogression if the aqueous fluid flows in a pervasive way, but to veining of quartz-rich assemblages if the aqueous fluid flows in a focused way. Anatexis of UHP rocks may also take place at elevated temperatures [15].

Metamorphic dehydration and partial melting are facilitated by structural shearing of crustal fragments and slices in continental subduction channels. The aqueous fluid and hydrous melt are generated from UHP metamorphic rocks during their exhumation from mantle depths to crustal levels [16-19]. As such, there are not only physical mixing but also chemical reaction at the slab-mantle interface (Figure 2). Such fluid/melt would flow along the slab-mantle interface and rise into the overlying SCLM wedge, leading to chemical reaction with the mantle wedge peridotite to generate mafic to ultramafic metasomes [7]. The mantle metasomes may be stored in orogenic lithospheric mantle for few to tens of millions of years, serving as mantle sources for synexhumation alkali magmatism [20] and postcollisional mafic magmatism [21-26]. The dynamic structure of the jelly sandwich that formed during continental subduction would become a static structural of the jelly sandwich in the orogenic lithosphere subsequent to the exhumation of deeply subducted continental crust. This is a kind of the tectonic architecture in which the mantle metasomes is located in the upper, the exhumed upper crustal UHP slice in the middle and the exhumed lower crustal UHP slice in the lower. Such sandwich structure typical of continental collision zone has been imaged in the Dabie orogen not only by geophysical observation [27,28] but also by geochemical analyses [21,29].

A combination of results from the study of petrology, numerical modelling, geophysics and geochemistry suggests at least three-stage processes during continental collision. First, crustal materials are detached from subducting continental lithosphere at different depths, suffering different extents of deformation and metamorphism along the interface between the subducted continental crust and the overlying SCLM wedge. Second, crust-derived materials are mixed not only with each other but also with peridotite fragments

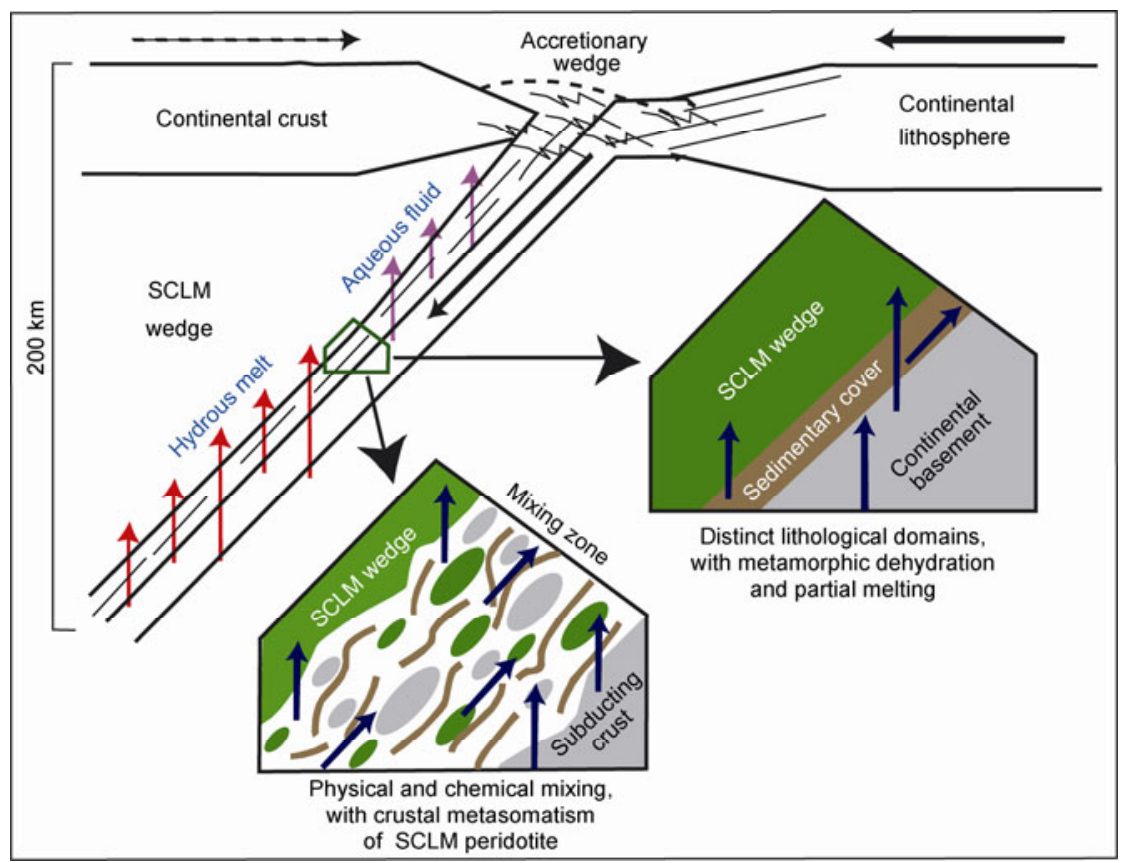

Figure 2 Sketch of a subduction channel at the plate interface in continental subduction zone (revised after Zheng et al. [3]). Two processes occur at the slabmantle interface in the subduction channel during continental collision, with physical mixing to produce tectonic melange of metamorphic rocks, and chemical reaction of the overlying subcontinental lithospheric mantle (SCLM) wedge with aqueous fluid and hydrous melt from subducting continental crust. 
scrapped from bottom of the SCLM wedge, yielding UHP mélanges at mantle depths. Third, the UHP mélanges are returned to crustal levels by the corner flow in the continental subduction channel, forming the exposed mélanges that exhibit variable P-T conditions and lithologies. Thus, variable extents of physical mixing and chemical reaction along the continental subduction channel are a key to the formation and exhumation of orogenic mélanges [7]. Consequently, all UHP metamorphic rocks in continental collision orogens can be viewed as three-component mixing systems that are primarily composed of continental basement and sedimentary cover with minor peridotite from the SCLM wedge. They are tectonic mélanges due to mechanical mixing of these three components in the continental subduction channel. Therefore, the subduction channel processes are the tectonic mechanism that can account for various occurrences of microscale to macroscale lithotectonic units in continental collision orogens.

The exhumation mechanism of UHP terranes from mantle depths to crustal levels has being the hotspot and forefront in the study of continental deep subduction [30,31]. The slab breakoff is a traditional model, in which subducting continental slab becomes wholly exhumed due to breakoff at the transition to the oceanic slab that is pulling the continental deep subduction [32,33]. The model of continental subduction channel has been used to explain exhumation of HP and UHP metamorphic rocks [34-36]. In terms of the continental subduction channel model [7], the subducting continental lithosphere is detached at different depths as crustal slices into the subduction channel that are sequentially exhumed toward the surface (Figure 3(a)). Then the subducting continental lithosphere is wholly exhumed due to breakoff from continuously subducted oceanic lithosphere (Figure 3(b)). The exhumed slices of continental crust underwent different extents of deformation and metamorphism under different P-T conditions, even if there is a significant difference in P-T path between different positions of the same slice. As a consequence, continental collision orogens normally exhibit the following tectonic architecture: the low-T/UHP slice is exhumed at first and thus located in the upper layer. It is followed by exhumation of the mid-T/UHP slice, which is located in the middle layer. The high-T/UHP slice is exhumed finally and thus located in the lower layer. During such differential exhumation, the deep UHP rocks may undergo granulite-facies overprinting to cause the heating dehydration. As such, the water liberated is pervasively migrated upwards and thus becomes the source of aqueous fluid for amphibolite-facies retrogression of the shallow UHP rocks.

Although there are hot debates on the tectonic mechanisms of exhuming HP and UHP terranes from mantle depths to crustal levels, various sizes and shapes of HP and UHP slices are indeed capable of being exhumed inside cold continental subduction channels. Both internal and external forces in the subduction channels have played the
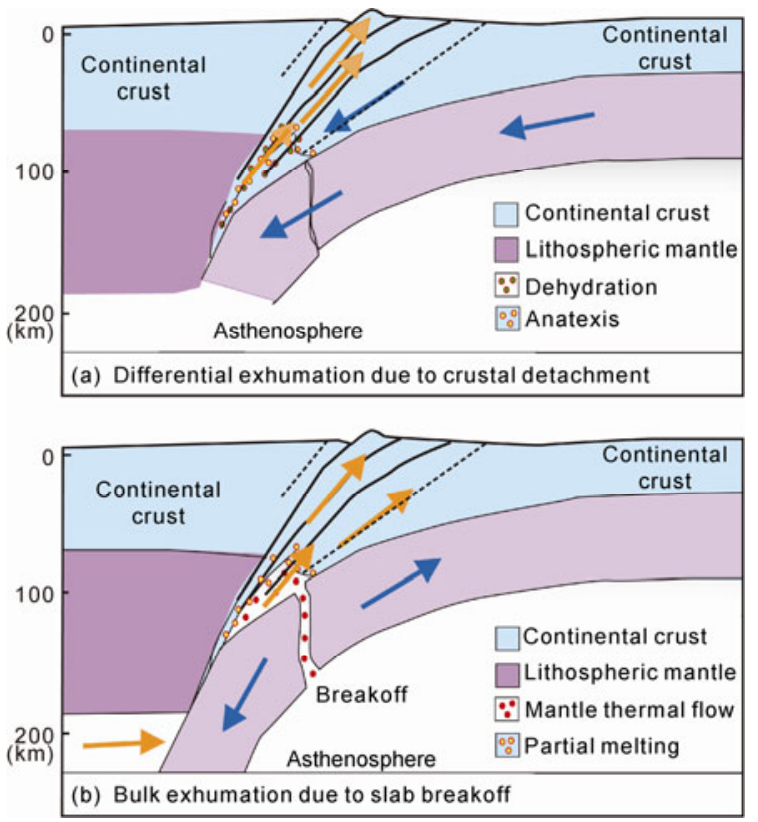

Figure 3 Schematic diagram for differential exhumation of subducted crustal slices during continental collision. (a) Differential exhumation of crustal slices in continental subduction channel due to detachment at different depths; (b) bulk exhumation of continental lithosphere due to breakoff from oceanic lithosphere.

roles of exhumation [37]. The internal force is indicated by the buoyancy-driven upward motion, including channel flow during ongoing continental subduction, wedge extrusion induced by the detachment of deeply subducted crustal materials from the downgoing lithosphere, and the diapiric ascent of subducted crustal materials under the action of flu$\mathrm{id} / \mathrm{melt}$. The external force is indicated by the upward flow of detached materials, involving large-scale intracrustal thrusting with coeval erosion, pure-shear thickening and coeval erosion during continental collision, decoupling and eduction of the continental crust and changes in lithospheric kinematics at convergent margins. A combination of the internal and external forces in the cold subduction channels can result in the varying extents of metamorphism with heterogeneous deformation and local anatexis of the subducted crustal materials at different depths, extents and fashions. It is also the primary mechanism for the differential exhumation of HP to UHP slices following the crustal detachment during continental collision. On the other hand, exhumation of UHP rocks may be driven by rollback of the deeply subducting continental lithosphere $[38,39]$. This can be explained by the assumption that the slab rollback causes an increase of the free space in the subduction channel, leading to the exhumation of UHP slices at the action of buoyancy.

\section{Protolith nature and continental collision}

The applications of subduction channel model to continental collision orogens enable us to focus on the lithotectonic 
property of subducted crust and its overlying mantle wedge. The subducted continental crust is primarily composed of basement granite, granulite and gabbro with sedimentary cover, containing very minor peridotite. It contains less water than the subducted oceanic crust that is primarily of altered oceanic basalt and gabbro with thin cover sediment. The mantle wedge above the subducting continental slab is of high viscosity, low temperature and low water fugacity, in contrast to the mantle wedge above the subducting oceanic slab that is of low viscosity, high temperature and high water fugacity. In view of the time of crust-mantle differentiation that can be defined by whole-rock $\mathrm{Nd}$ isotope ratios and protolith ages, two origins of crustal rocks can be distinguished in subducted continental crust [7]. One is the juvenile crust that is recently derived from partial melting of the mantle in mid-ocean ridge, island arc, backarc and rift tectonic zones, exhibiting a high radiogenic $\mathrm{Nd}$ isotope composition with positive $\varepsilon_{\mathrm{Nd}}(t)$ values. The other is the ancient crust that is commonly composed of Precambrian basement with respect to Phanerozoic metamorphic rocks, exhibiting a high unradiogenic $\mathrm{Nd}$ isotope composition with negative $\varepsilon_{\mathrm{Nd}}(t)$ values. Thus, juvenile arcs between collided continents can be inferred from the occurrence of positive $\varepsilon_{\mathrm{Nd}}(t)$ eclogites, whereas the ancient arcs of the continental margin are indicated by negative $\varepsilon_{\mathrm{Nd}}(t)$ eclogites.

Continental subduction zones are commonly transformed from intercontinental basins or backarc basins close to continental margins. Pulling of subducting oceanic slab serves as a driving force for subduction of continental slab to mantle depths. As such, continental subduction zones are commonly of composite origin and thus exhibit a large diversity in the protolith nature of UHP metamorphic rocks [7]. For example, in some subduction zones such as Alps-Himalaya and Tianshan-Ural, Tethys-type basalts of juvenile origin were subducted to mantle depths for UHP metamorphism. But in other subduction zones such as Dabie-Sulu of China and Western Gneiss Region of Norway, the continental basement of ancient origin was subducted to mantle depths for UHP metamorphism. In either case, the configuration of subduction zones is uniform in that the mantle wedge is always present between the subducting continental crust and the overriding continental crust. In the Andean-type subduction zones where the oceanic lithosphere is subducted beneath the continental lithosphere, the overlying mantle wedge may be of juvenile origin due to the accretion of oceanic arc terranes. In the Alpine-type subduction zones, on the other hand, the continental lithosphere is subducted beneath the continental lithosphere and the overlying mantle wedge may be of either ancient origin (craton mantle) or juvenile origin (subarc mantle).

Although there are various types of orogens on Earth, they are generally categorized into accretionary-type and collision-type in terms of their tectonic evolution and protolith nature. With respect to the collision-type orogen, arccontinent collision is developed from subduction of conti- nental crust beneath arc-type terrane (e.g., Himalaya and Papua New Guinea) whereas continent-continent collision is developed from subduction of continental lithosphere beneath continental lithosphere (e.g., Dabie-Sulu of China, Western Gneiss Region of Norway) [7]. Many accretionary-type orogens are developed into continent-arc-continent collision orogens in their advanced stage, so that they are referred as accretionary-type arc-continent collision orogens [37]. Different origins of crustal rocks were subducted to mantle depths for UHP metamorphism during continental collision. The difference in protolith origin is correlated with the type of collisional orogens and the size of UHP terranes [7]. In arc-continent collision orogens, mafic UHP eclogites primarily have the protolith of juvenile basalts whereas felsic UHP gneisses mostly have the protolith of accretionary wedge sediments that may be derived from weathering of either ancient or juvenile crustal rocks. In continent-continent collision orogens, on the other hand, protolith of the eclogites is primarily ancient mafic rocks whereas protolith of the gneisses is mostly ancient granites with minor amounts of continental sediment. In either case, very small volumes of the UHP eclogites are enclosed by very large volumes of the UHP gneisses in various UHP terranes [2,7].

Despite their variation in metamorphic ages from the Early Paleozoic to the Late Cenozoic, durations of UHP metamorphism fall into two groups in light of the available geochronological data [40,41]. One group exhibits short durations in a few millions of years (e.g., the Dora Maira of Western Alps, the Kaghan Valley of Himalaya, and the Woodlark of Papua New Guinea), whereas the other group exhibits long durations in tens of millions of years (e.g., Dabie-Sulu of China, Western Gneiss Region of Norway). The two groups of metamorphic durations are generally correlated with the area of exposed UHP eclogite-facies rocks (terrane size) and the protolith nature of UHP terranes (Figure 4). Small UHP terranes are commonly of juvenile

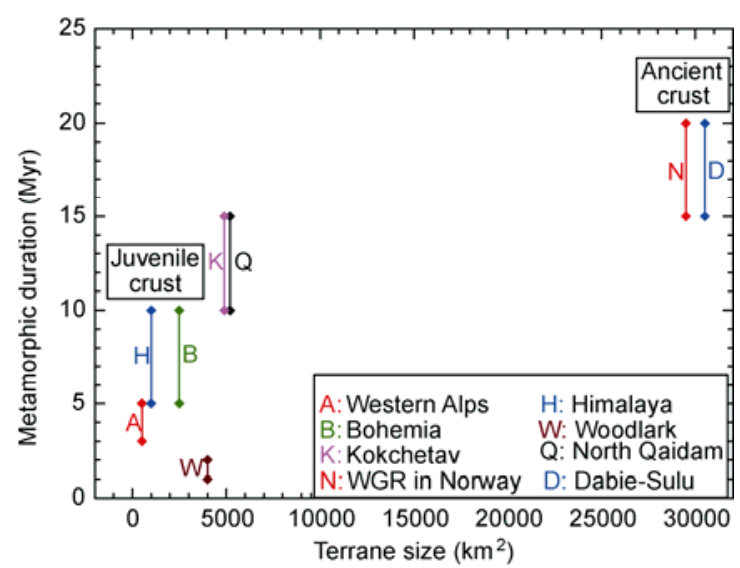

Figure 4 The relationship between UHP terrane size and metamorphic duration (data after Zheng [7]). Small UHP terranes contain fragments of the juvenile crust and exhibit short residence at mantle depths, whereas large UHP terranes contain no fragments of juvenile crust and exhibit long residence at mantle depths. 
crustal protoliths and tend to metamorphose over the short timescales with rapid rates of exhumation, whereas large UHP terranes are generally of ancient crustal protoliths and tend to metamorphose over the long timescales with slow rates of exhumation. These two types of relationships can be well explained by the subduction channel processes during continental collision: the small UHP terranes are much more susceptible to motion than the large UHP terranes in subduction channel. Therefore, the nature of premetamorphic protoliths dictates the type of collisional orogens, the size of ultrahigh-pressure metamorphic terranes and the duration of ultrahigh-pressure metamorphism [7].

During the continental collision, the continental crust was subducted either beneath the juvenile subarc lithosphere (e.g., Alps-Himalaya, Tianshan-Ural) or beneath the ancient craton lithosphere (e.g., Dabie-Sulu, Western Gneiss Region). The former corresponds to the accretionary-type arc-continent collision that results in wide orogens with intervened arc terranes, whereas the latter corresponds to the continent-continent collision that leads to narrow orogens without intervened arc terranes [7]. Within the framework of plate tectonics, there are a series of processes from oceanic subduction to continental collision [37]: (1) subduction of the Tethys-type lithosphere beneath the Tethys-type lithosphere to cause oceanic arc magmatism, (2) rollback of subducting slab to cause backarc basin extension and magmatism, (3) the closure of backarc basins in association with the Andes-type arc-continent collision, (4) subduction of the Tethys-type lithosphere beneath the newly accreted arc terranes to cause continental arc magmatism, (5) subduction of the ancient continental lithosphere beneath the newly accreted arc terrane to cause the Himalaya-type arc-continent collision (e.g., Dora Maira, Kaghan Valley and Woodlark). While UHP metamorphism of the subducted crustal rocks is common in the Himalaya-type arc-continent collision orogens, it is absent in the Andes-type arc-collision orogens; (6) subduction of the ancient continental lithosphere beneath the ancient continental lithosphere to cause the continent-continent collision (e.g., Dabie-Sulu, Western Gneiss Region).

\section{Summary}

The study of plate interface interaction is a significant step to develop the plate tectonic theory from oceanic subduction to continental collision. Subduction channels are a focus of the interaction between Earth's surface and interior; physical coupling and chemical reaction between convergent plates dictate the mechanical transfer and material transport of subduction zones. Thus, the purpose of highlighting the subduction channel processes is to decipher the processes and products of plate interface interaction in subduction zones. In order to develop the chemical geodynamics of subduction zones, further studies are required to determine the dimension, geometry size and physicochemical property of the plate interface, to quantify the fluxes of fluid and mass through and along the plate interface by bridging space and time scales through the combination of petrological and geochemical data, and to model the relationships between mineralogical reactions, fluid flow and element mobilization in various lithologies. Because of the difference and importance of aqueous fluid, hydrous melt and supercritical fluid in dissolving and transporting various elements, it is also intriguing to know how these fluids are generated and evolved in subduction zones and how they become effective on geochemical processes at the plate interface.

By extending the subduction channel model to continental subduction zones, not only the framework of plate tectonics is provided for the origin of lithotectonic units in continental collision orogens, but also the light of chemical geodynamics is shed on crust-mantle interaction in continental subduction zones. The crust-mantle interaction in continental subduction channel is realized by chemical reaction between the subducted crust-derived fluid/melt and the overlying SCLM wedge peridotite. Materials inside the subduction channel are very ductile with respect to its hangwall (mantle peridotite) and footwall (crustal basement). Felsic metamorphic rocks in the subduction channel have lower density and viscosity than mafic counterparts and thus are susceptible to transport upward. Crustal fragments in the subduction channel can be transported either downwards with prograde metamorphism during subduction, or upwards with retrograde metamorphism during exhumation, or even with rotation. As a consequence, the metamorphic rocks of continental subduction zones experience overprinted processes, exhibiting not only the polyphase growth/recrystallization of metamorphic minerals but also the episodic action of metamorphic fluid.

The processes in continental subduction channel have left notable and directly accessible records at the surface in the form of exhumed UHP metamorphic terranes. While the formation of UHP metamorphic rocks is due to further subduction of HP rocks with the downgoing slab, the differential exhumation of UHP metamorphic crustal slices is primarily driven by the corner flow in the continental subduction channel. Small UHP terranes of juvenile crustal protolith resided at mantle depths in short durations with rapid exhumation, whereas large UHP terranes of ancient crustal protolith resided at mantle depths in long durations with slow exhumation. However, the concret mechanism of exhumation for different lithotectonic units may vary from case to case, depending on the temporal and spatial positioning in the subduction channel with the competition between internal and external forces. Therefore, there are various types of physical mixing and chemical reaction between crust- and mantlederived rocks in the continental subduction channel.

This work was supported by the National Natural Science Foundation of China (41221062) and the Ministry of Science and Technology of China (2009CB825004). 
1 Chopin C. Ultrahigh-pressure metamorphism; tracing continental crust into the mantle. Earth Planet Sci Lett, 2003, 212: 1-14

2 Liou J G, Ernst W G, Song S G, et al. Tectonics and HP-UHP metamorphism of northern Tibet-Preface. J Asian Earth Sci, 2009, 35: 191-198

3 Zheng Y-F, Zhang L F, McClelland W C, et al. Processes in continental collision zones: Preface. Lithos, 2012, 136-139: 1-9

4 Shreve R L, Cloos M. Dynamics of sediment subduction, mélange formation, and prism accretion. J Geophys Res, 1986, 91B: 10229 10245

5 Cloos M, Shreve R L. Subduction-channel model of prism accretion, mélange formation, sediment subduction, and subduction erosion at convergent plate margins, 1, Background and description. Pure Appl Geophys, 1988, 128: 456-500

6 Cloos M, Shreve R L. Subduction-channel model of prism accretion, mélange formation, sediment subduction, and subduction erosion at convergent plate margins, 2, Implications and discussion. Pure Appl Geophys, 1988, 128: 501-505

7 Zheng Y-F. Metamorphic chemical geodynamics in continental subduction zones. Chem Geol, 2012, 328: 5-48

8 Beaumont C, Ellis S, Pfiffner A. Dynamics of sediment subductionaccretion at convergent margins: Short-term modes, long-term deformation, and tectonic implications. J Geophys Res, 1999, B104: 17573-17601

9 Gerya T V, Stöckhert B, Perchuk A L. Exhumation of high-pressure metamorphic rocks in a subduction channel: A numerical simulation. Tectonics, 2002, 21: 1056

10 Guillot S, Hattori K, Agard P, et al. Exhumation processes in oceanic and continental subduction contexts: A review. In: Lallemand S, Funiciello F, eds. Subduction Zone Geodynamics. Berlin Heidelberg: Springer-Verlag, 2009. 175-205

11 Zheng Y-F, Fu B, Gong B, et al. Stable isotope geochemistry of ultrahigh pressure metamorphic rocks from the Dabie-Sulu orogen in China: implications for geodynamics and fluid regime. Earth Sci Rev, 2003, 62: 105-161

12 Zheng Y-F, Zhou J-B, Wu Y-B, et al. Low-grade metamorphic rocks in the Dabie-Sulu orogenic belt: A passive-margin accretionary wedge deformed during continent subduction. Intern Geol Rev, 2005, 47: 851-871

13 Rubatto D, Regis D, Hermann J, et al. Yo-yo subduction recorded by accessory minerals in the Italian Western Alps. Nat Geosci, 2011, 4: 338-342

14 Zheng Y-F. Fluid regime in continental subduction zones: Petrological insights from ultrahigh-pressure metamorphic rocks. J Geol Soc Lond, 2009, 166: 763-782

15 Zheng Y-F, Xia Q-X, Chen R-X, et al. Partial melting, fluid supercriticality and element mobility in ultrahigh-pressure metamorphic rocks during continental collision. Earth Sci Rev, 2011, 107: 342-374

16 Zhao Z-F, Zheng Y-F, Chen R-X, et al. Element mobility in mafic and felsic ultrahigh-pressure metamorphic rocks during continental collision. Geochim Cosmochim Acta, 2007, 71: 5244-5266

17 Xia Q-X, Zheng Y-F, Zhou L-G. Dehydration and melting during continental collision: Constraints from element and isotope geochemistry of low-T/UHP granitic gneiss in the Dabie orogen. Chem Geol, 2008, 247: 36-65

18 Gao X-Y, Zheng Y-F, Chen Y-X. Dehydration melting of ultrahighpressure eclogite in the Dabie orogen: Evidence from multiphase solid inclusions in garnet. J Metamorph Geol, 2012, 30: 193-212

19 Chen Y-X, Zheng Y-F, Hu Z. Synexhumation anatexis of ultrahigh-pressure metamorphic rocks: Petrological evidence from granitic gneiss in the Sulu orogen. Lithos, 2013, 156-159: 69-96

20 Zhao Z-F, Zheng Y-F, Zhang J, et al. Syn-exhumation magmatism during continental collision: Evidence from alkaline intrusives of Triassic age in the Sulu orogen, Chem Geol, 2012, 328: 70-88
21 Zhao Z-F, Zheng Y-F, Wei C-S, et al. Origin of postcollisional magmatic rocks in the Dabie orogen: Implications for crust-mantle interaction and crustal architecture. Lithos, 2011, 126: 99-114

22 Dai L-Q, Zhao Z-F, Zheng Y-F, et al. Zircon Hf-O isotope evidence for crust-mantle interaction during continental deep subduction. Earth Planet Sci Lett, 2011, 308: 224-244

23 Dai L-Q, Zhao Z-F, Zheng Y-F, et al. The nature of orogenic lithospheric mantle: Geochemical constraints from postcollisional maficultramafic rocks in the Dabie orogen. Chem Geol, 2012, 334: 99-121

24 Yang Q-L, Zhao Z-F, Zheng Y-F. Modification of subcontinental lithospheric mantle above continental subduction zone: Constraints from geochemistry of Mesozoic gabbroic rocks in southeastern North China. Lithos, 2012, 146-147: 164-182

25 Yang Q-L, Zhao Z-F, Zheng Y-F. Slab-mantle interaction in continental subduction channel: Geochemical evidence from Mesozoic gabbroic intrusives in southeastern North China. Lithos, 2012, 155: $442-460$

26 Zhang J, Zhao Z-F, Zheng Y-F, et al. Zircon Hf-O isotope and wholerock geochemical constraints on origin of postcollisional mafic to felsic dykes in the Sulu orogen. Lithos, 2012, 136-139: 225-245

27 Dong S-W, Li Q-S, Gao R, et al. Moho-mapping in the Dabie ultrahigh-pressure collisional orogen, Central China. Am J Sci, 2008, 308: 517-528

28 Luo Y H, Xu Y X, Yang Y J. Crustal structure beneath the Dabie orogenic belt from ambient noise tomography. Earth Planet Sci Lett, 2012, 313-314: 12-22

29 Zhao Z-F, Zheng Y-F, Wei C S, et al. Zircon U-Pb ages, Hf and O isotopes constrain the crustal architecture of the ultrahigh-pressure Dabie orogen in China. Chem Geol, 2008, 253: 222-242

30 Sizova E, Gerya T V, Brown M. Exhumation mechanisms of meltbearing ultrahigh pressure crustal rocks during collision of spontaneously moving plates. J Metamorph Geol, 2012, 30: 927-955

31 Warren C. Exhumation of (ultra-)high-pressure terranes: Concepts and mechanisms. Solid Earth, 2013, 4: 75-92

32 Davies J H, von Blanckenburg F. Slab break off: A model of lithosphere detachment and its test in the magmatism and deformation of collisional orogens. Earth Planet Sci Lett, 1995, 129: 85-102

33 von Blanckenburg F, Davies J H. Slab breakoff: A model for syncollisional magmatism and tectonics in the Alps. Tectonics, 1995, 14: $120-131$

34 Lardeaux J M, Ledru P, Daniel I, et al. The Variscan French Massif Central-A new addition to the ultrahigh pressure metamorphic 'club': Exhumation processes and geodynamic consequences. Tectonophysics, 2001, 332: 143-167

35 Beaumont C, Jamieson R A, Butler J P, et al. Crustal structure: A key constraint on the mechanism of ultra-high-pressure rock exhumation. Earth Planet Sci Lett, 2009, 287: 116-129

$36 \mathrm{Li} \mathrm{Z} \mathrm{H}$, Gerya T V. Polyphase formation and exhumation of high- to ultrahigh pressure rocks in continental subduction zone; numerical modeling and application to the Sulu ultrahigh-pressure terrane in eastern China. J Geophys Res, 2009, 114: B09406

37 Zheng Y-F, Xiao W-J, Zhao G C. Introduction to tectonics of China. Gondwana Res, 2013, 23: 1189-1306

38 Brun J-P, Faccenna C. Exhumation of high-pressure rocks driven by slab rollback. Earth Planet Sci Lett, 2008, 272: 1-7

39 Husson L, Brun J-P, Yamoto P, et al. Episodic slab rollback fosters exhumation of HP-UHP rocks. Geophys J Intern, 2009, 179: 1292-1300

40 Zheng Y-F, Chen R-X, Zhao Z-F. Chemical geodynamics of continental subduction-zone metamorphism: Insights from studies of the Chinese Continental Scientific Drilling (CCSD) core samples. Tectonophysics, 2009, 475: 327-358

41 Kylander-Clark A R C, Hacker B R, Mattinson C G. Size and exhumation rate of ultrahigh-pressure terranes linked to orogenic stage. Earth Planet Sci Lett, 2012, 321-322: 115-120

Open Access This article is distributed under the terms of the Creative Commons Attribution License which permits any use, distribution, and reproduction in any medium, provided the original author(s) and source are credited. 